\title{
Seasonal variation in carbon dioxide exchange over a Mediterranean annual grassland in California
}

\author{
Liukang $\mathrm{Xu}^{*}$, Dennis D. Baldocchi \\ Ecosystem Science Division, Department of Environmental Science, Policy and Management, 151 Hilgard Hall, \\ University of California at Berkeley, Berkeley, CA 94720, USA
}

Received 2 June 2003; received in revised form 4 October 2003; accepted 10 October 2003

\begin{abstract}
Understanding how environmental variables affect the processes that regulate the carbon flux over grassland is critical for large-scale modeling research, since grasslands comprise almost one-third of the earth's natural vegetation. To address this issue, fluxes of $\mathrm{CO}_{2}\left(F_{\mathrm{c}}\right.$, flux toward the surface is negative) were measured over a Mediterranean, annual grassland in California, USA for 2 years with the eddy covariance method.

To interpret the biotic and abiotic factors that modulate $F_{\mathrm{c}}$ over the course of a year we decomposed net ecosystem $\mathrm{CO}_{2}$ exchange into its constituent components, ecosystem respiration $\left(R_{\text {eco }}\right)$ and gross primary production (GPP). Daytime $R_{\text {eco }}$ was extrapolated from the relationship between temperature and nighttime $F_{\mathrm{c}}$ under high turbulent conditions. Then, GPP was estimated by subtracting daytime values of $F_{\mathrm{c}}$ from daytime estimates of $R_{\mathrm{eco}}$.

Results show that most of carbon exchange, both photosynthesis and respiration, was limited to the wet season (typically from October to mid-May). Seasonal variations in GPP followed closely to changes in leaf area index, which in turn was governed by soil moisture, available sunlight and the timing of the last frost. In general, $R_{\text {eco }}$ was an exponential function of soil temperature, but with season-dependent values of $Q_{10}$. The temperature-dependent respiration model failed immediately after rain events, when large pulses of $R_{\text {eco }}$ were observed. Respiration pulses were especially notable during the dry season when the grass was dead and were the consequence of quickly stimulated microbial activity.

Integrated values of GPP, $R_{\text {eco }}$, and net ecosystem exchange (NEE) were 867, 735, and $-132 \mathrm{~g} \mathrm{C} \mathrm{m}^{-2}$, respectively, for the 2000-2001 season, and 729, 758, and $29 \mathrm{~g} \mathrm{C} \mathrm{m}^{-2}$ for the 2001-2002 season. Thus, the grassland was a moderate carbon sink during the first season and a weak carbon source during the second season. In contrast to a well-accepted view that annual production of grass is linearly correlated to precipitation, the large difference in GPP between the two seasons were not caused by the annual precipitation. Instead, a shorter growing season, due to late start of the rainy season, was mainly responsible for the lower GPP in the second season. Furthermore, relatively higher $R_{\text {eco }}$ during the non-growing season occurred after a late spring rain. Thus, for this Mediterranean grassland, the timing of rain events had more impact than the total amount of precipitation on ecosystem GPP and NEE. This is because its growing season is in the cool and wet season when carbon uptake and respiration are usually limited by low temperature and sometimes frost, not by soil moisture.
\end{abstract}

(C) 2003 Elsevier B.V. All rights reserved.

Keywords: Net ecosystem carbon exchange; Gross primary production; Ecosystem respiration; Soil moisture; Friction velocity

\section{Introduction}

* Corresponding author. Tel.: +1-510-6422421; fax: +1-510-6435098.

Understanding how gross primary production E-mail address: 1kxu@nature.berkeley.edu (L. Xu). (GPP) and ecosystem respiration $\left(R_{\text {eco }}\right)$ respond to 
environmental variables and how these carbon flux components vary on daily, seasonal, annual and interannual temporal scales are prerequisites for understanding what controls and modulates net ecosystem exchange (NEE) of ecosystems and biomes (Law et al., 1999). Since carbon fluxes of biomes respond differently to environmental forcing variables and their perturbations, it is essential to characterize the physiological responses for each major biome.

It is also imperative to assess the relationship between GPP and canopy structure over a variety of ecosystems. Such data are needed to validate indices that are being evaluated with reflectance data measured by instruments on satellite-based remote sensing platforms - normalized difference vegetation index (NDVI) - to upscale carbon assimilation fluxes to regional, continental and global scales (Running et al., 1999; Turner et al., 1999; Myneni et al., 2002; Wylie et al., 2003).

At present, most long-term carbon flux studies have focused on various temperate conifer and broadleaved (deciduous and evergreen) forests, tropical and boreal forests. Only a few long-term carbon flux studies have been conducted over grasslands (Meyers, 2001; Flanagan et al., 2002; Suyker et al., 2003; Gilmanov et al., 2003), even though grassland is the largest of the four major natural biomes (Sims and Risser, 2000).

Grasslands growing in temperate continental areas are perennial and their growing season is limited to the warm summer. Consequently, temperature, precipitation, photosynthesis and respiration are in phase with one another. From a functional perspective, biogeographic conditions and natural selection have interacted to produce grasslands where a significant fraction of species use the $\mathrm{C}_{4}$ photosynthetic pathway (Ham and Knapp, 1998; Kim and Verma, 1990; Ehleringer et al., 1997).

While both perennial and annual grasslands exist, the majority of carbon flux studies over grasslands have been restricted to continental regions. Mediterranean grasslands, in contrast, are functional during the winter and early spring and are dead during the summer, as temperature is out phase with precipitation (Bartolome, 1979; Chiariello, 1989). Consequently, the length of its growing season depends on the timing of the beginning and end of the rainy season. And because the growing season is during the cool, wet winter Mediterranean regions consist mainly of annual
$\mathrm{C}_{3}$ species (Huenneke and Mooney, 1989; Ehleringer et al., 1997).

At the ecosystem scale, grasslands can be either net carbon sources or sinks. Depending on precipitation, more carbon uptake occurs during wet years and vice versa (Flanagan et al., 2002; Meyers, 2001; Suyker et al., 2003). These physiological results, based on the eddy covariance method, are consistent with numerous ecological studies, which have shown that aboveground net primary production (ANPP) of grasslands growing in the continental region of North America is correlated linearly with annual precipitation (Sims and Singh, 1978; Webb et al., 1978; Sala et al., 1988; Paruelo et al., 1999; Lauenroth and Sala, 1992; Knapp and Smith, 2001).

Studies on the micrometeorological and ecophysiological control on the carbon exchange of annual grasslands in California are rare (Barbour and Minnich, 2000). Only Valentini et al. (1995) has published measurements of carbon and water use of Californian grassland, but their study period was not on a continuous basis for a full year. Furthermore, it was specific to grass growing on serpentine soil near the Pacific coast and in an urban air-shed area.

Several arguments can be forwarded to articulate a need for long-term carbon flux measurements over annual, $\mathrm{C}_{3}$ grassland ecosystems in California. First, they are model ecosystems for studying the environmental perturbation of ecosystem carbon fluxes. Specifically, they experience modulations of temperature, rainfall, soil moisture and leaf area index across a wider range of environmental conditions than are observed over mesic and temperate ecosystems that are more commonly studied by sites across the AmeriFlux and FLUXNET networks (e.g. Baldocchi et al., 2001; Law et al., 2002). This unique feature provides us with the ability to define the light-, temperature- and soil moisture-response functions for carbon uptake and ecosystem respiration better. Secondly, because the grasslands experience distinct wet and dry periods they provide us with a better ability to quantify how carbon gain and water loss compete as the soil moisture pool is depleted.

In this paper, we report a 2-year carbon flux study over California grassland. The main objective is to quantify NEE of the grassland and its partitioning into GPP and $R_{\text {eco }}$ using eddy covariance technique. Specifically, we examine the seasonal and interannual 
variability in carbon exchange in term of biotic and environmental drivers. Three specific questions that are addressed with our data are: (1) How do the two major components of carbon balance (i.e. GPP and $R_{\text {eco }}$ ) respond to changes in grass phenology, soil moisture and temperature? (2) How does the seasonal distribution and total amount of precipitation affect GPP and $R_{\text {eco }}$ ? (3) What is the interannual variation of NEE, GPP and $R_{\text {eco }}$ of an annual grassland? Information on water and energy exchange from this grassland is reported separately (Baldocchi et al., 2003).

\section{Materials and methods}

\subsection{Site description, climate, soil and grass species}

The research site is a grazed grassland opening in a region of oak/grass woodland. It was established in October 2000 as part of the AmeriFlux network (Law et al., 2003). It is located on the foothills of the Sierra Nevada Mountains, and is about $35 \mathrm{~km}$ southeast of Sacramento $\left(38^{\circ} 24.400 \mathrm{~N}, 120^{\circ} 57.044 \mathrm{~W}\right.$, and $129 \mathrm{~m}$ a.s.1.).

The soil is an Exchequer very rocky silt loam (Lithic xerorthents). It contains 30\% sand, 57\% silt and $13 \%$ clay. Its bulk density at surface layer $(0-30 \mathrm{~cm})$ is around $1.43 \pm 0.10 \mathrm{~g} \mathrm{~cm}^{-3}(n=27)$. Total nitrogen and carbon content of the soil were about 0.14 and $1.39 \%$, respectively. The soil profile is about $0.5 \mathrm{~m}$ deep, and overlays fractured rock.

The climate at the site is Mediterranean type with clear days, high temperatures, and virtually no rainfall during the summer. In contrast, the winter is relatively cold and wet. The mean annual temperature was $16.2{ }^{\circ} \mathrm{C}$ during 2001 and $566 \mathrm{~mm}$ of precipitation fell. These values are close to climatic means, determined over 30 years from a nearby weather station at Ione, $\mathrm{CA}$ (mean air temperature is $16.3^{\circ} \mathrm{C}$ and mean precipitation is $559 \mathrm{~mm}$ ).

The grassland is dominated by cool-season $\mathrm{C}_{3}$ annual species. More than $95 \%$ of species composition at the site, are Brachypodium distachyon L., Hypochaeris glabra L., Trifolium dubium Sibth., Trifolium hirtum All., Dichelostemma volubile A., and Erodium botrys Cav. The maximum grass height in the peak growth period (late April to early May) could reach up to $0.55 \pm 0.12 \mathrm{~m}(n=25)$.

\subsection{Flux measurement}

The flux of $\mathrm{CO}_{2}$ over the grassland was measured continuously with an eddy covariance system. The fetch from all directions is more than $200 \mathrm{~m}$. Calculations with a footprint model (Schmid, 1994) indicated that the fetch was well within the flux footprint. The flux system, which was mounted at $2 \mathrm{~m}$ above the ground, consisted of a 3D sonic anemometer (Model 1352, Gill Instruments Ltd., Lymington, England) and an open-path and fast response infrared gas analyzer (IRGA, Li 7500, Li-Cor Inc., Lincoln, NE, USA). The anemometer and the IRGA provide digital output of the fluctuations in three wind components $(w, u, v)$, sonic temperature $\left(T_{\mathrm{S}}\right)$, water vapor $\left(\rho_{\mathrm{v}}\right)$ and $\mathrm{CO}_{2}$ density $\left(\rho_{\mathrm{c}}\right)$. The raw data from each $30 \mathrm{~min}$ period were recorded at the rate of $10 \mathrm{~Hz}$ into separate files on a laptop computer. Spectra and co-spectra computations show that these sampling rates are adequate for measuring fluxes with this configuration.

The IRGA was swapped out every month with a newly calibrated one. The $\mathrm{CO}_{2}$ signal of the IRGA was calibrated against gas mixtures in air that were referenced to standards prepared by NOAA's Climate Monitoring \& Diagnostics Laboratory (NOAA/CMDL). The span for the water vapor was calibrated with a dew point generator (model Li-610, Li-Cor Inc., Lincoln, NE, USA). Zeros for both $\mathrm{CO}_{2}$ and water vapor channels were calibrated with $99.99 \%$ nitrogen gas after passing through soda lime and magnesium perchlorate. Calibration results showed that the cumulative deviations for zero drift and span change for both $\mathrm{CO}_{2}$ and water vapor channels over a period of one full year were less than 3 and $1 \%$, respectively. Thus, shifts of zero and span over a month period can be considered as insignificant.

The eddy flux system was powered by eight 12 VDC deep cycle batteries that were charged by eight solar panels (Model SP75, Siemens) in wintertime and six panels in the rest time of a year. The system used approximately $3 \mathrm{~A}$ at $12 \mathrm{~V}$.

\subsection{Meteorology, soil and other parameter measurements}

Along with the flux measurements with the eddy covariance technique, standard meteorological and soil parameters were measured continuously with an array 
of sensors. Photosynthetic photon flux density, $Q_{\mathrm{p}}$, reflected $Q_{\mathrm{p}}$, and $R_{\mathrm{n}}$ were measured with a quantum sensor (Kipp and Zonen PAR-Lite, Delft, Holland) and a net radiometer at the height of $2.5 \mathrm{~m}$ (Kipp and Zonen, Delft, Holland), respectively. Precipitation was measured with a tipping-bucket rain gauge (Texas Electronics, Texas). Air temperature and relative humidity at the height of $2.5 \mathrm{~m}$ were measured with a shielded and aspirated sensor (HMP-35 A, Vaisala, Helsinki, Finland). Soil temperature at the depths of 0.02, 0.04, $0.08,0.16$ and $0.32 \mathrm{~m}$ were measured with three multiple-level thermocouple sensors. Soil volumetric water content was measured with frequency-domain reflectometer probe (ML2x, Delta-T Devices, Burwell, Cambridge, UK) at depths of 0.05, 0.10 and $0.20 \mathrm{~m}$. Profiles of soil moisture (at the depth of $0-0.15,0.15-0.30,0.30-0.45$, and $0.45-0.60 \mathrm{~m}$ ) were also measured weekly with a time-domain reflectometers (Moisture Point, model 917, Environmental Sciences Inc., Vancouver, Canada) over much larger sample area. Soil heat flux was obtained by averaging the output of three heat flux plates (model HFP-01, Hukseflux Thermal Sensors, Delft). They were buried $0.01 \mathrm{~m}$ below the surface and were randomly placed within a few meters of the flux system. All channels from meteorological and soil sensors, except the rain gauge, were scanned every $5 \mathrm{~s}$ with data-loggers (CR10X or CR23X, Campbell Scientific Inc., Logan, UT, USA), and then 30 min mean data were stored. The $30 \mathrm{~min}$ mean data were retrieved by the laptop computer used for the eddy covariance measurement.

Leaf area index (LAI) was determined at intervals of 2-4 weeks. Grass was harvested from four sample plots $(0.25 \mathrm{~m} \times 0.25 \mathrm{~m})$ in the prevailing direction of eddy covariance flux system. Then leaves were separated from the stem and their areas were measured with a leaf area meter (Li-Cor 3100, Lincoln, NE, USA).

\subsection{Data processing and flux computation}

Standard micrometeorological software was used to compute flux covariances from the raw data. Computations included spike removal, coordinate rotation, and application of standard gas laws. In practice, the analytical method used to measure $\mathrm{CO}_{2}$ has an impact on the computation of the flux covariance. When $\mathrm{CO}_{2}$ is measured with an infrared spectrometer one samples molar density, $\rho_{\mathrm{c}}$ (moles per unit volume). In principle, changes in molar density can occur by adding molecules to or removing them from a controlled volume or by changing the size of the controlled volume, as is done when pressure, temperature and humidity change in the atmosphere. By measuring the eddy flux covariance in terms of molar density, the net flux density of $\mathrm{CO}_{2}\left(F_{\mathrm{c}}\right)$ across the atmosphere-biosphere interface can be expressed as

$F_{\mathrm{c}}=\overline{w \rho_{\mathrm{c}}}=\overline{w^{\prime} \rho_{\mathrm{c}}^{\prime}}+\overline{w \rho_{\mathrm{c}}}$

The first term on the right-hand side of Eq. (1) is the covariance between the fluctuations of vertical velocity $\left(w^{\prime}\right)$ and $\mathrm{CO}_{2}$ density $\left(\rho_{\mathrm{c}}^{\prime}\right)$. The second term is the product of the mean vertical velocity $(\bar{w})$ and $\mathrm{CO}_{2}$ density $\left(\overline{\rho_{\mathrm{c}}}\right)$. The mean vertical velocity is non-zero and arises from air density fluctuations (Webb et al., 1980). The magnitude of $\bar{w}$ is too small $\left(<1 \mathrm{~mm} \mathrm{~s}^{-1}\right)$ to be detected by sonic anemometry, so it is usually computed on the basis of temperature $(T)$ and humidity density $\left(\rho_{\mathrm{V}}\right)$ fluctuations using the Webb-Pearman-Leuning (1980) algorithm:

$F_{\mathrm{c}}=\overline{w^{\prime} \rho_{\mathrm{c}}^{\prime}}+\frac{m_{\mathrm{a}}}{m_{\mathrm{v}}} \overline{\overline{\rho_{\mathrm{c}}}} \overline{\overline{\rho_{\mathrm{a}}}} \overline{w^{\prime} \rho_{\mathrm{v}}^{\prime}}+\left(1+\frac{\overline{\rho_{\mathrm{v}}} m_{\mathrm{a}}}{\overline{\rho_{\mathrm{a}}} m_{\mathrm{v}}}\right) \overline{\frac{\rho_{\mathrm{c}}}{\bar{T}}} \overline{w^{\prime} T^{\prime}}$

Other variables in Eq. (2) are the molecular weights of air, $m_{\mathrm{a}}$, and water vapor, $m_{\mathrm{v}}$, dry air density, $\rho_{\mathrm{a}}$. From Eq. (2), positive $F_{\mathrm{c}}$ represents the ecosystem losing carbon via respiration, whereas negative indicates the net carbon gain via photosynthesis.

To assess the accuracy of the eddy covariance measurements, we analyzed linear regressions between the sum of latent heat (LE), sensible heat $(H)$ and soil heat flux $(G)$ vs net radiation $\left(R_{\mathrm{n}}\right)$ :

$\mathrm{LE}+H+G=a_{0}+a R_{\mathrm{n}}$

At the beginning of this study, we were able to attain a high degree of closure of the surface energy balance. During 2000, the intercept, slope and $r^{2}$ were 5.5, 0.94 and 0.93 , respectively. As the experiment continued into 2001 and 2002 we observed degradation in the degree of energy balance closure. However, we did not observe any systematic changes from upper envelopes of seasonal trends in net radiation, sensible heat flux and latent heat flux. Close inspection of the 
data showed that the long-term degradation in closing the surface energy balance was an artifact of measuring soil heat flux within a cow-proof enclosure. The enclosure had more plant matter and detritus than the surrounding paddock and this caused the magnitude and amplitude of soil heat flux to lower with time. When the change in heat storage term above soil heat flux plates was taken into account, the regression, defined by Eq. (3), exceeded 0.90 for both year 2001 and 2002 (Baldocchi et al., 2003).

\subsection{Methods for gap filling, low $U^{*}$ correction and estimating GPP and $R_{\mathrm{eco}}$}

For long-term and continuous field measurements, missing data is unavoidable due to malfunction of the instrumentations or power failure. From the 2-year measurements, we missed about $17.3 \%$ of data in 2001 and $8.2 \%$ in 2002 . Another $13.5 \%$ of data points were rejected in 2001 and $10.9 \%$ in 2002 due to the bad statistics of certain turbulent variables, e.g. Reynolds stress, skewness and kurtosis of $w$ and $\rho_{\mathrm{c}}$ signals, or off normal scales of $T_{\mathrm{s}}, \rho_{\mathrm{v}}$, or $\rho_{\mathrm{c}}$. In order to obtain the information on the annual sum of the carbon flux data, we used the following procedure to fill missing and bad data. For small blocks (less than an hour) of missing data, simple interpolation method was used. Larger blocks of missing data during the growing season were filled by using a rectangular hyperbolic light-response function (Falge et al., 2001):

$F_{\mathrm{c}}=\frac{F_{\max } \alpha Q_{\mathrm{p}}}{\alpha Q_{\mathrm{p}}+F_{\max }}+R_{\mathrm{eco}}$

where $Q_{\mathrm{p}}\left(\mu \mathrm{mol} \mathrm{m}{ }^{-2} \mathrm{~s}^{-1}\right)$ is incident photosynthetically active radiation, $F_{\max }\left(\mu \mathrm{mol} \mathrm{m} \mathrm{m}^{-2} \mathrm{~s}^{-1}\right)$ the maximum $\mathrm{CO}_{2}$ flux at infinite light, $\alpha$ the apparent quantum yield, and $R_{\text {eco }}$ the respiration from soil and plants; we tried other types of light-response functions, and results showed those functions did not provide a better fit to Eq. (4).

Nighttime missing data were filled by using the following exponential relationship between $F_{\mathrm{c}}$ from periods of high turbulence when the friction velocity $\left(U^{*}\right)$ was higher than $0.1 \mathrm{~m} \mathrm{~s}^{-1}$ and soil temperature at depth of $0.04 \mathrm{~m}\left(T_{\text {soil }}\right)$ :

$F_{\mathrm{c}}=b_{0} \exp \left(b T_{\text {soil }}\right)$ where $b_{0}$ and $b$ are two empirical coefficients, from which $Q_{10}$ can be estimated as

$Q_{10}=\exp (10 b)$

The reason we chose the soil temperature at the depth of $0.04 \mathrm{~m}$ in this analysis is that it reduced the sources of variation most for regression of Eq. (5) than that at other depths. The soil temperature function (Eq. (5)) was also used to extrapolate daytime ecosystem respiration. During the non-growing summer period, all missing, rejected data were filled or replaced by using Eq. (5).

We also corrected $F_{\mathrm{c}}$ for the $\mathrm{CO}_{2}$ storage term before gap filling to avoid double counting (Aubinet et al., 2002). Since we did not have $\mathrm{CO}_{2}$ profile data, the $\mathrm{CO}_{2}$ storage term was estimated only based on the one point $\mathrm{CO}_{2}$ concentrations from the open-path IRGA of the eddy covariance system. This approach might be an acceptable estimation, since the height of our flux system was only at $2 \mathrm{~m}$ high, and because the storage term sums to zero on daily and annual time scales (Baldocchi, 2003).

GPP was obtained by subtracting $R_{\text {eco }}$ from NEE (Barr et al., 2002; Flanagan et al., 2002), which required us to evaluate $R_{\text {eco }}$ for day and nighttime periods. Because of the strong seasonality in grass phenology and in soil moisture, we evaluated the respiration temperature coefficient, $Q_{10}$, using short, 5-daytime windows, for the fast transition periods. During the non-growing summer season, when soil moisture changed little, we used 1-month time window.

\section{Results and discussion}

\subsection{Weather conditions and canopy structure}

In order to study the carbon exchange between the grassland and the atmosphere, it is necessary to first understand the seasonality of key environmental variables. Seasonal variations in daily maximum $\left(T_{\max }\right)$ and minimum $\left(T_{\min }\right)$ air temperature, daily precipitation (PPT), volumetric soil water content $\left(\theta_{\mathrm{v}}\right)$, reflectivity of $Q_{\mathrm{p}}(\gamma)$, and LAI are presented in Fig. 1.

There were pronounced variations in temperature during the growing season. $T_{\max }$ ranged from moderate levels $\left(\sim 10^{\circ} \mathrm{C}\right)$ in the winter and early spring to extreme levels $\left(>40^{\circ} \mathrm{C}\right)$ by early summer during the 


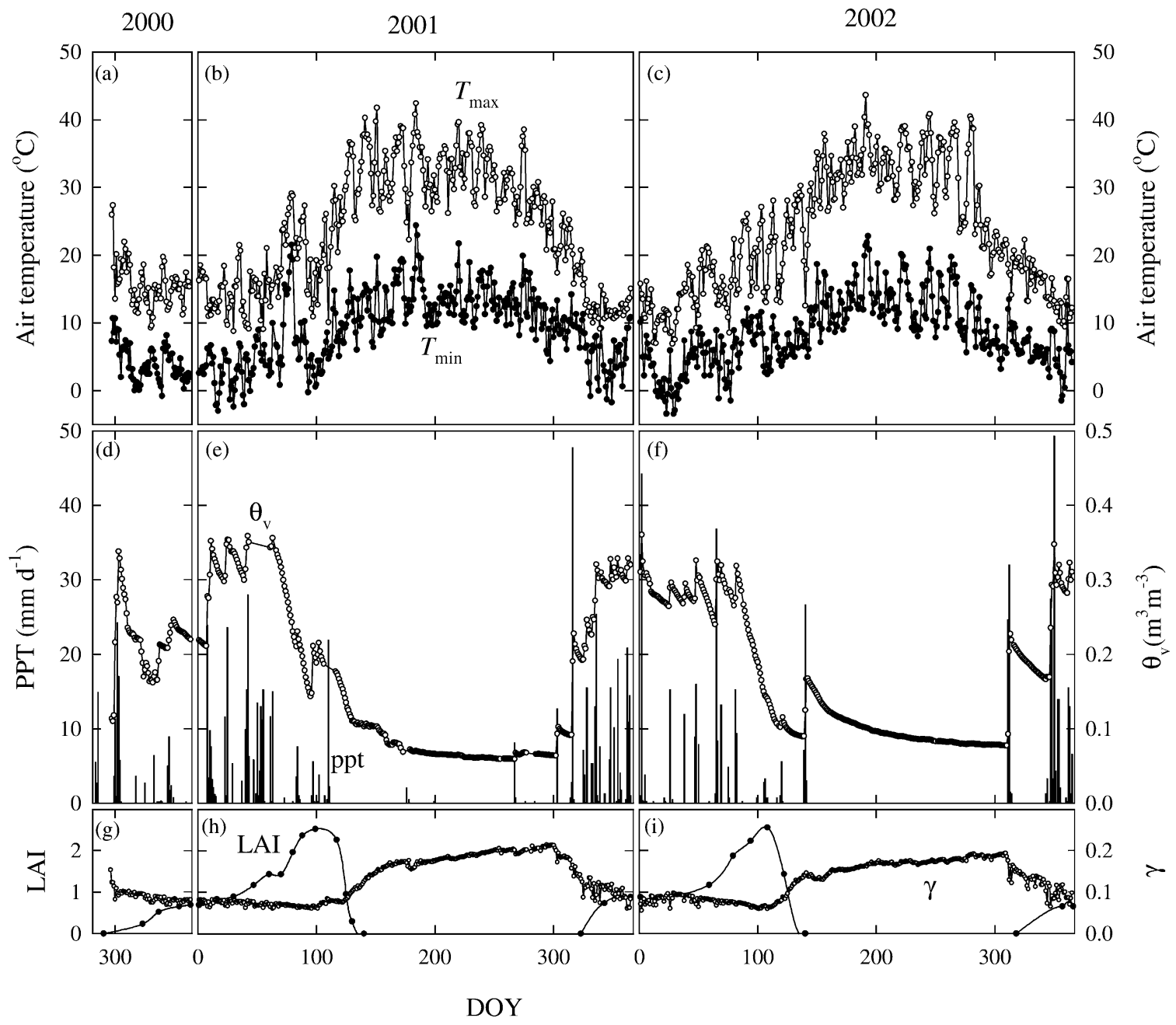

Fig. 1. Seasonal variation of major meteorological variables over the course of the study. Data shown in the top three panels ((a)-(c)) are maximum $\left(T_{\max }\right)$ and minimum air temperature $\left(T_{\min }\right)$. Daily total precipitation $(\mathrm{PPT})$ and averaged volumetric soil water moisture $\left(\theta_{\mathrm{v}}\right)$ from the depth of $0.05,0.10$, and $0.20 \mathrm{~m}$ are shown in the middle three panels ((d)-(f)). Leaf area index (LAI) and $Q_{\mathrm{p}}$ albedo $(\gamma)$ were also shown ((g)-(i)). $\gamma$ was $Q_{\mathrm{p}}$-weighted averaged when PAR $>100 \mu \mathrm{mol} \mathrm{m}{ }^{-2} \mathrm{~s}^{-1}$.

grass senescence period. The wide temperature range encountered by the ecosystem over the course of a day is also worth noting. In summer temperature it was well over $25^{\circ} \mathrm{C}$. Even in winter and early spring it could be as large as $15^{\circ} \mathrm{C}$ (Fig. $1 \mathrm{~b}$ and c).

Due to the Mediterranean climate, about $98 \%$ of precipitation fell during the wet seasons (i.e. from October to April). Annual precipitation during 2001 and 2002 was 567 and $494 \mathrm{~mm}$, respectively. The precipitation in both years was not significantly different from the normal, which was $559 \mathrm{~mm}$. Winter rainfall provided enough moisture to recharge the soil profile. During the wet season, $\theta_{\mathrm{v}}$ (weighted-average from $0.05,0.10$, and $0.20 \mathrm{~m}$ ) was around $0.30 \mathrm{~m}^{3} \mathrm{~m}^{-3}$ or higher. When the wet season was over, $\theta_{\mathrm{v}}$ declined within a month to a low steady state value in the range of $0.07-0.10 \mathrm{~m}^{3} \mathrm{~m}^{-3}$ (Fig. 1e and f). Vigorous growth of grass, combined with a shallow soil profile, relatively light soil texture, and high evaporative demand, contributed this rapid depletion of soil moisture. This large seasonal variation in $\theta_{\mathrm{v}}$, along with the wide range of diel and seasonal temperature, provides us a 
unique opportunity to better define temperature- and moisture-response curves of carbon flux of the ecosystem.

Timing of rainfall is also important. In the second season there was a large storm just after the grass senescence; the storm produced $37 \mathrm{~mm}$ precipitation over the period of 3 days (19-21 May 2002). Because transpiration ceased after the grass died and soil evaporation was chronically low, $\theta_{\mathrm{v}}$ was consistently $0.02-0.04 \mathrm{~m}^{3} \mathrm{~m}^{-3}$ higher during the summer non-growing season in 2002 than in the previous year. This had a great impact on the soil respiration, as we will demonstrate below.

Because of the shallow rooting depth, the grass phenology closely followed soil moisture, which in turn depended on the rainfall. Grass seed germination normally occurs in the fall, 1 week after a major rain event with total precipitation of at least $15 \mathrm{~mm}$ (Bartolome, 1979; Chiariello, 1989). One such rain event occurred on 10 October for the 2000-2001 growing season, 1 month earlier as compared to 11 November for the second season. As a result, the grass germinated almost 1 month earlier in the first season. After germination, due to low soil and air temperature and occasional frosts, the grass underwent a period of slow vegetative growth in the wintertime as we can see from LAI data in both seasons (Fig. 1g-i). In the spring, warming temperatures, longer day length, and ample soil moisture accelerated the grass growth to a peak period with the maximum LAI of around 2.5 for the two seasons. The peak growth period did not last very long. Shortly after the wet season was over and most of the available soil moisture was utilized, the grass quickly senesced-around DOY140 for both seasons-leaving dormant grass seeds to transmit biological activity across the dry and hot summer.

Fig. 1 also illustrates the seasonal variations in $Q_{\mathrm{p}}$ albedo $(\gamma)$, which was determined with an upwardand downward-facing quantum sensors. To avoid low solar angles when $\gamma$ was not truly representative of the canopy surface, $\gamma$ data were $Q_{\mathrm{p}}$-weighted average when incident $Q_{\mathrm{p}}$ values were higher than $100 \mu \mathrm{mol} \mathrm{m}^{-2} \mathrm{~s}^{-1}$. The seasonal change in $\gamma$ was almost like the mirror image of variations in LAI, showing that $\gamma$ decreased gradually as canopy size developed. Whereas during the fast senescenced phase in the late spring when LAI plummeted to zero in just 3 weeks, $\gamma$ jumped up correspondingly. Such strong negative relationship between $\gamma$ and LAI suggests that $\gamma$ could be used as an alternative parameter to quantify the canopy activity when LAI information is not available. In fact, a study from a central Okalahoma tallgrass prairie showed that sometimes $\gamma$ was even a better parameter than LAI to describe transitional periods of vegetation activity, including the end of peak growth, the entire pre-grow and post-burn periods (Burba and Verma, 2001).

\subsection{Response of nighttime $F_{\mathrm{c}}$ to temperature}

As we described above, nighttime gap filling were based on the soil temperature function (i.e. $Q_{10}$ relation, Eq. (5)) of the $R_{\text {eco }}$ obtained under strong turbulence conditions $\left(U^{*}>0.1 \mathrm{~m} \mathrm{~s}^{-1}\right)$. To avoid the confounding effects of grass phenology and soil moisture on the temperature function (Luo et al., 1996; Xu and Qi, 2001a; Flanagan et al., 2002), we developed a specific response curve for different time windows, sometimes as short as 5 days, during which both LAI and $\theta_{\mathrm{v}}$ changed little. Fig. 2a shows three examples of temperature function from DOY129 to DOY139 (late senescence), DOY180 to DOY230 (non-growing season), and DOY347 to DOY365 (winter, LAI < 1.0) in 2001. The exponential function of Eq. (5) described the relationships between soil temperature at $0.04 \mathrm{~m}$ and $R_{\text {eco }}$ very well. From Eq. (6), $Q_{10}$ was estimated to be $2.5,2.2$, and 2.1 for the three examples, respectively.

High $Q_{10}$ values from the present study were observed in wet season when grass was very active, whereas low $Q_{10}$ values were mostly from nongrowing summertime, a reflection of the different temperature sensitivities for autotrophic and heterotrophic respiration and the turnover times of the multiple carbon pools. High temperature sensitivity may include the direct physiological effect of temperature on root and microbial activities and the indirect effect related to photosynthetic assimilation and carbon allocation to roots (Davidson et al., 1998). Evidence for the indirect effect of photosynthesis on autotrophic respiration comes from a series of recent studies (Bremer et al., 1998; Högberg et al., 2001; Bowling et al., 2002). During the dry season, the main portion of ecosystem respiration comes from the more recalcitrant carbon material, which has been shown to have low temperature sensitivity (Liski et al., 1999). Thus, in modeling 


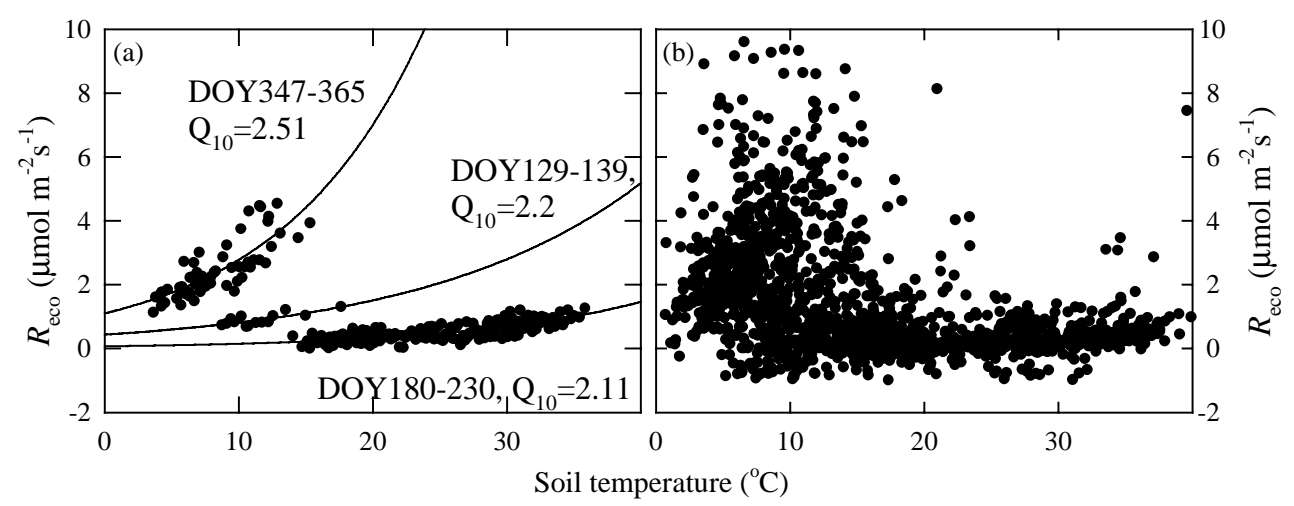

Fig. 2. Response of ecosystem respiration $\left(R_{\text {eco }}\right)$ to change in soil temperature at the depth of $4 \mathrm{~cm}$. Data were from 2000 to 2001 season, and were $3 \mathrm{~h}$ binned. Data in (a) were three examples from different growth periods each with similar LAI and soil moisture content. While in (b), data across the whole season were presented.

long-term ecosystem respiration, one should account for how $Q_{10}$ varies over the season with changes in soil moisture, temperature and phenology.

The measured values of $Q_{10}$ were close to the mean value deduced from a global survey of soil respiration (Raich and Schlesinger, 1992). A wider variation in $Q_{10}$ values has been reported in the literature as soil moisture drops (Davidson et al., 1998; Xu and Qi, 2001a) or as soil temperature increases (Tjoelker et al., 2001). For example, Xu and Qi (2001b) reported that $Q_{10}$ varied from 1.0 to 2.2 from a study conducted at a Sierra Nevada forest. Davidson et al. (1998) reported that $Q_{10}$ for soil respiration ranged from 3.4 to 5.6 for different study sites in a temperate mixed hardwood forest. Considering variations in soil moisture, Reichstein et al. (2002b) reported a significant decline in $Q_{10}$ (from 0.5 to 2.6) when the soil moisture dropped for three Mediterranean evergreen sites.

When $R_{\text {eco }}$ was plotted against soil temperature over the whole season (Fig. 2b), no single temperature function was found to describe the variations in $R_{\text {eco }}$. The maximum $R_{\text {eco }}$ occurred when the soil temperature was around $7-13^{\circ} \mathrm{C}$, soil moisture was ample, and the grass was experiencing its peak growth period. $R_{\text {eco }}$ declined to less than $1.0 \mu \mathrm{mol} \mathrm{m}{ }^{-2} \mathrm{~s}^{-1}$ during the non-growing season when soil temperature was above $15^{\circ} \mathrm{C}$ and $\theta_{\mathrm{v}}$ was less than $0.10 \mathrm{~m}^{3} \mathrm{~m}^{-3}$. These results clearly indicates that the potential to enhance ecosystem respiration, by temperature during the dry season, is countered the inhibition due to severe drought.

\subsection{Response of daytime $F_{\mathrm{c}}$ to incident radiation}

Because photosynthesis is driven by light, we first examine how $F_{\mathrm{c}}$ responds to changes in $Q_{\mathrm{p}}$. Because the structure and function of the grassland changes appreciably over the year we examine this relation for four different phenoseasons (Fig. 3). In general, the rectangular hyperbolic function can be used to describe the relationship between $Q_{\mathrm{p}}$ and $F_{\mathrm{c}}$ with success. Except for the fourth period, which was from the senescent phase (Fig. 3d), no clear light saturation of $F_{\mathrm{c}}$ was observed, even at LAI of less than 1.0. Based on the statistical analysis by using Eq. (4), the regression coefficients indicated that changes in $Q_{\mathrm{p}}$ accounted for more than $80 \%$ of the variations in $F_{\mathrm{c}}$. The $F_{\max }$ for the first three growing periods (Fig. 3a-c) was $-10.8,-24.6$, and $-40.2 \mu \mathrm{mol} \mathrm{m}^{-2} \mathrm{~s}^{-1}$, respectively, and $\alpha$ was $0.014,0.023$, and 0.024 . The quantum yield was well within the range of published data for $C_{3}$ grasses (Ruimy et al., 1995), and was very close to the value from other eddy covariance studies over temperate $\mathrm{C}_{3}$ grassland (e.g. Flanagan et al., 2002). The low $\alpha$ at early season was most likely due to small canopy size, low temperature, and immature leaves. At the end of the senescence phase (DOY130-140, Fig. 3d), $F_{\mathrm{c}}$ increased along with $Q_{\mathrm{p}}$ in the early morning, and then showed a trend of decrease as $Q_{\mathrm{p}}$ further increased. This result is probably due to enhanced ecosystem respiration with increasing in temperature.

Seasonal changes in the diurnal patterns of $\mathrm{CO}_{2}$ exchange can provide insights on $Q_{\mathrm{p}}$ and LAI interact 


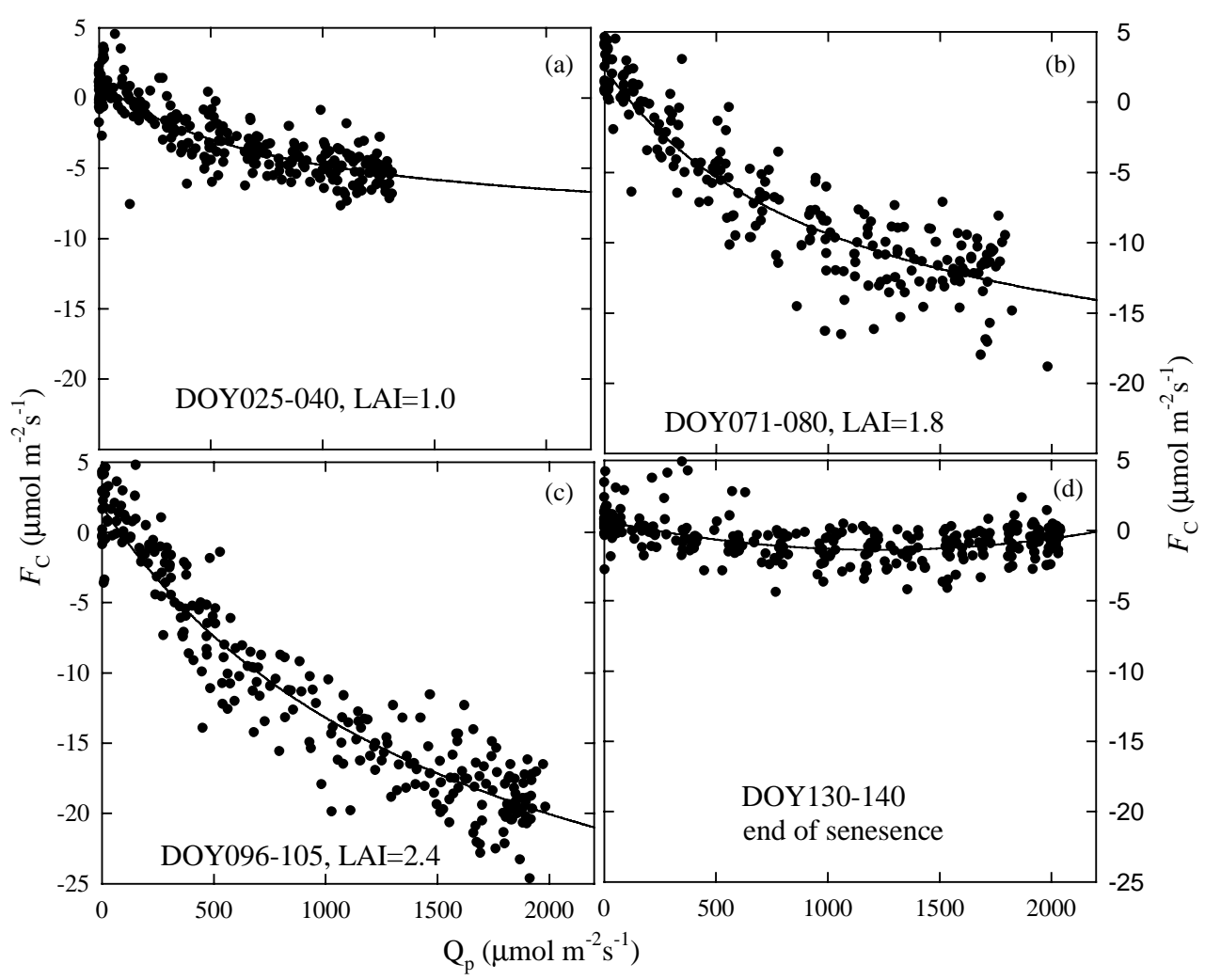

Fig. 3. Examples of light-response curves of $\mathrm{CO}_{2}$ flux $\left(F_{\mathrm{c}}\right)$ at different growth stages from 2001 to 2002 growing season. Fitted curves are rectangular hyperbolic as described in Eq. (4), except in (d) which is quadratic polynomial. The growth stage and its leaf area (LAI) are also given.

to control photosynthesis and respiration. Mean diurnal courses of $F_{\mathrm{c}}$ and $Q_{\mathrm{p}}$ from different growth period are presented in Fig. 4, to illustrate this point; data were binned from five consecutive days to reduce the sampling error. Both examples were from sunny days with ample soil moisture. One was from wintertime during DOY031-035 in 2001 when LAI was 1.0 , and the other from the peak growth period during DOY101-105 in 2002 with LAI of 2.2. The diurnal course of $F_{\mathrm{c}}$ depended mainly on LAI and $Q_{\mathrm{p}}$, showing a similar temporal pattern to the $Q_{\mathrm{p}}$ curves. The maximum $F_{\mathrm{c}}$ for the two cited periods, -9.0 and $-19.5 \mu \mathrm{mol} \mathrm{m}{ }^{-2} \mathrm{~s}^{-1}$, respectively, was centered around noontime. There was no consistent difference in the relationship between $F_{\mathrm{c}}$ and $Q_{\mathrm{p}}$ between morning and afternoon, indicating unlimited soil moisture conditions for grass carbon uptake. The observed values of $F_{\mathrm{c}}$ for this $\mathrm{C}_{3}$, annual grassland was in the mid- dle range of the values reported from other grassland studies. For example, Valentini et al. (1995) observed the maximum rate of $\mathrm{CO}_{2}$ uptake to range between -6 and $-8 \mu \mathrm{mol} \mathrm{m}^{-2} \mathrm{~s}^{-1}$ over a serpentine grassland in California. In contrast, much higher maximum rates of $\mathrm{CO}_{2}$ uptake (between -30 and $-40 \mu \mathrm{mol} \mathrm{m}^{-2} \mathrm{~s}^{-1}$ ) have been reported from more productive perennial grasslands, which contain $\mathrm{C}_{4}$ species (Kim and Verma, 1990; Suyker and Verma, 2001; Dugas et al., 1999). Also noted from Fig. 4 is that nighttime $R_{\text {eco }}$ was much higher for the peak growth stage than for the early season, reflecting importance of photosynthetic activity on the ecosystem respiration.

\section{4. $G P P$ in relation to $L A I$ and $R_{\mathrm{eco}}$}

Over the course of the growing season, day-today variations in GPP, on sunny days, were highly 


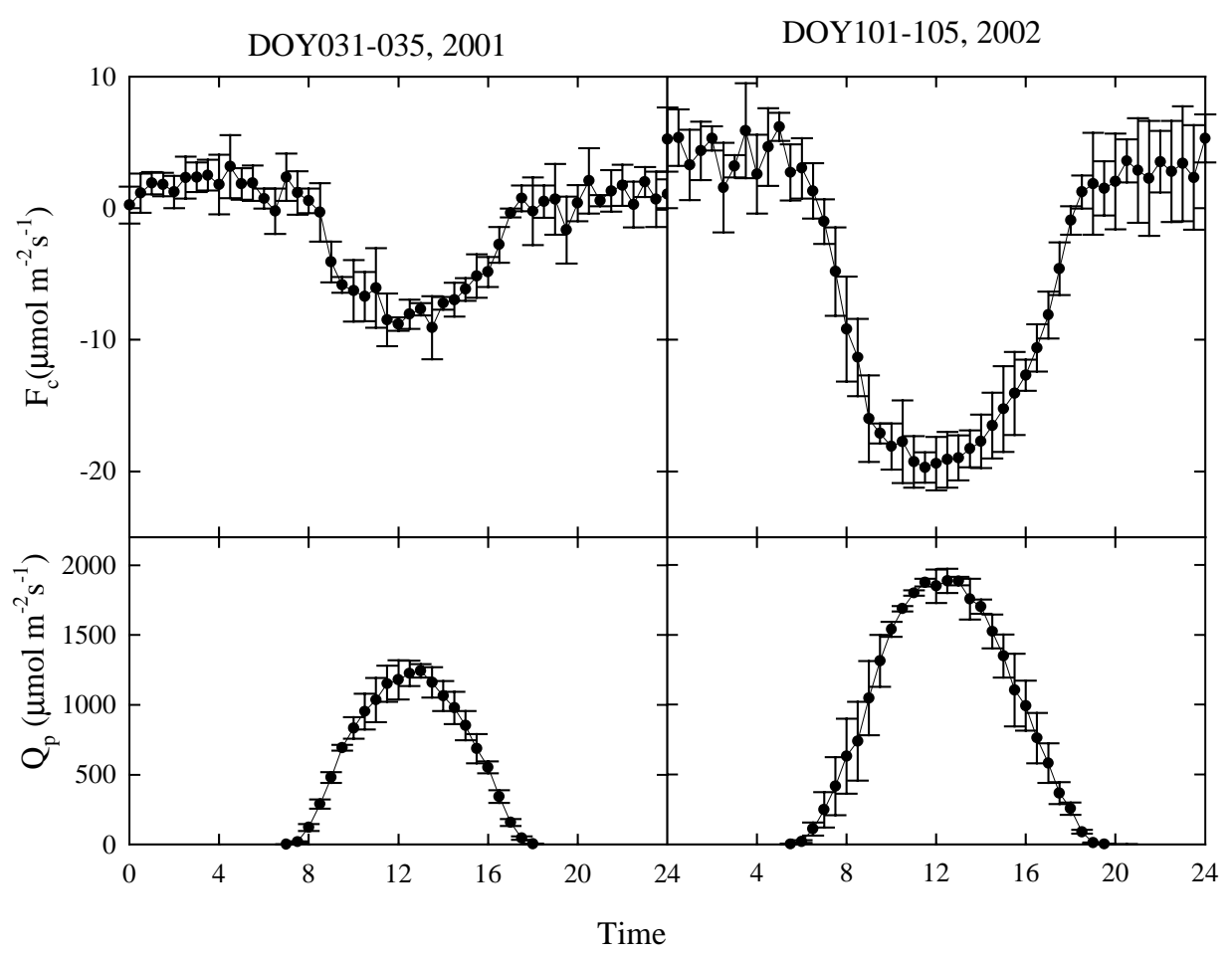

Fig. 4. Examples of 5-day binned diurnal variations in $\mathrm{CO}_{2}$ flux $\left(F_{\mathrm{c}}\right)$ and photosynthetic active radiation $\left(Q_{\mathrm{p}}\right)$ growth periods. DOY031-035, 2001 and DOY101-105, 2002. LAI was around 1.0 and 2.2, respectively. Error bars represent the standard deviation.

correlated with variations in LAI (Fig. 5). For this annual grassland, over $84 \%$ of the variance in GPP was explained by changes in LAI. The remaining $16 \%$ of the variance was due to variations in other weather/soil variables, such vapor pressure deficit, temperature, direct and diffuse radiation and soil moisture. In general, GPP increased by about $3.9 \mathrm{~g} \mathrm{C} \mathrm{m}^{-2}$ per day for each incremental increase in LAI. The linear relationship we observed is consistent with other grassland studies (Saigusa et al., 1998; Flanagan et al., 2002), but the slope we report is smaller than the one reported by Flanagan et al. (2002) for a continental grassland (7-9 $\mathrm{g} \mathrm{C} \mathrm{m}^{-2}$ per day per LAI).

Evidence exists in the literature that plant respiration can be scaled from plant photosynthesis, but only a few studies have presented information on GPP and ecosystem respiration (Law et al., 2002). When $R_{\text {eco }}$ was plotted against GPP, we found that there was a strong linear relation $\left(r^{2}=0.78\right.$, Fig. 6). This result indicates that $R_{\text {eco }}$ was more closely related to the canopy photosynthetic activity than to tempera- ture. These results are in agreement with a number of recent studies that have demonstrated a close linkage between the photosynthesis activity and respiration. For example, based on carbon flux data from 18 sites across European forests, Janssens et al. (2001) found that productivity of forests overshadows temperature in determining soil and ecosystem respiration. A study by Högberg et al. (2001) in a boreal pine forest in Sweden showed that up to $37 \%$ decrease in soil respiration was detected within 5 days after the stem bark of pine trees was girdled. Thus, the exponential function for ecosystem respiration (Eq. (5)) holds for a limited time period when LAI and soil moisture are similar. Therefore, in simulating $R_{\text {eco }}$ across the whole season, the impact of canopy photosynthesis activity must be taken into account (Janssens et al., 2001). Most recent results have shown that there is a time lag for $R_{\text {eco }}$ to respond the change in photosynthesis (Ekbald and Högberg, 2001; Bowling et al., 2002), making it more challenging to model ecosystem respiration. 


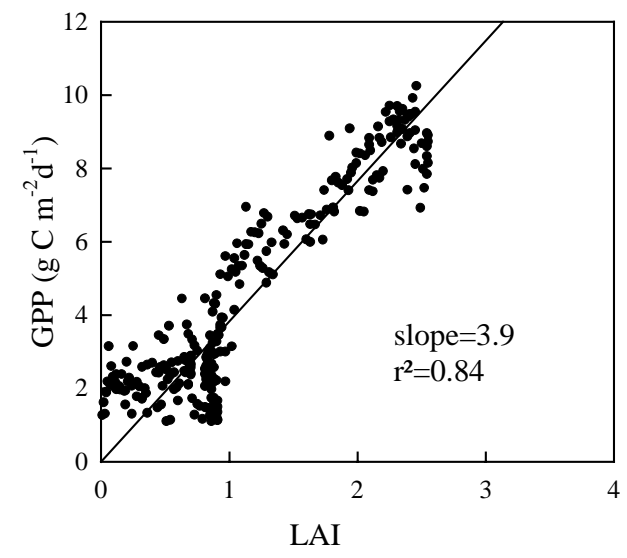

Fig. 5. The relationship of daily total gross primary production (GPP) and leaf area index (LAI). Data were obtained from the whole study period. GPP data from sunny days only and the linear regression was forced to pass through zero.

\subsection{Influence of rain events on $R_{\mathrm{eco}}$}

We observed large pulses of $R_{\text {eco }}$ immediately after individual rain events, especially during the summer dry period, when the grass was dead. Examples from year 2001 are presented in Fig. 7. The first rain event occurred late evening on DOY267 and lasted

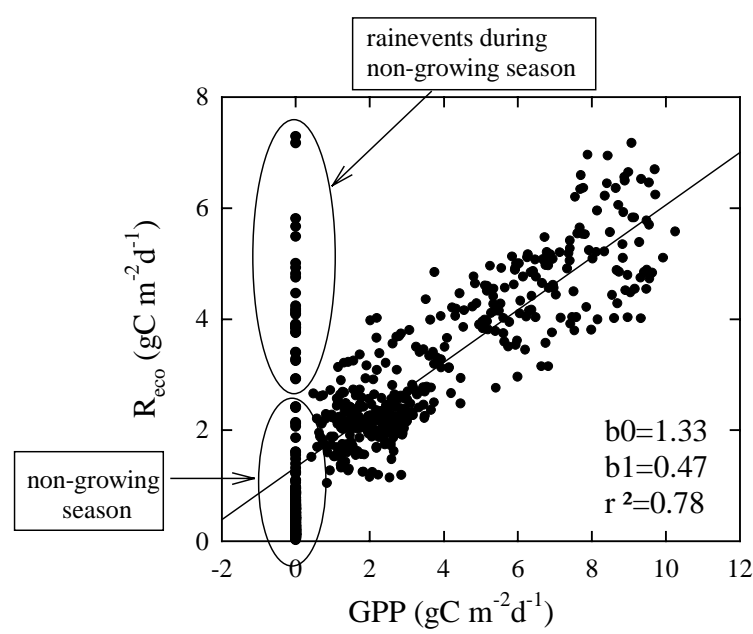

Fig. 6. The linear relation between daily gross primary production $(\mathrm{GPP})$ and ecosystem respiration $\left(R_{\text {eco }}\right)$. Data were compiled from the whole study period. Data points from rain events and non-growing seasons were excluded in the linear regression analysis.

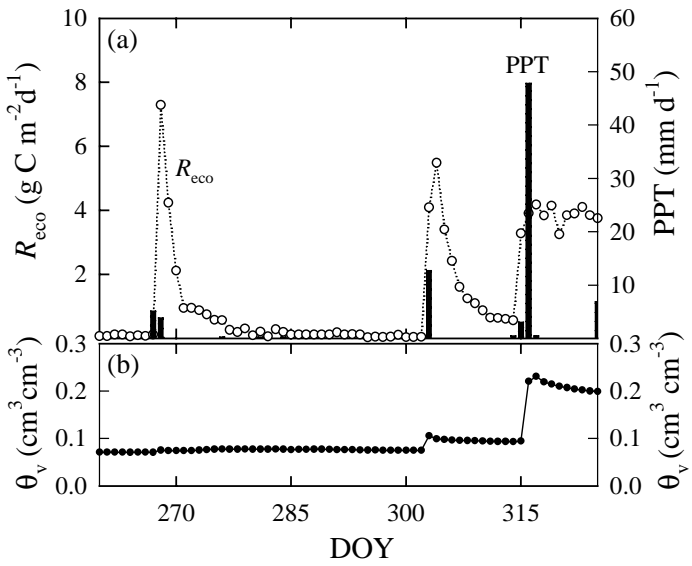

Fig. 7. Examples of influence of rain events on the ecosystem respiration $\left(R_{\text {eco }}\right)$ from year 2001 . Data in (a) are the daily total $R_{\text {eco }}$ and precipitation (PPT) and in (b) are volumetric soil moisture content $\left(\theta_{\mathrm{v}}\right)$ as averaged from the depth of $0.05,0.10$ and $0.20 \mathrm{~m}$.

until early in the morning on the next day. The total precipitation was only $8.9 \mathrm{~mm}$, and soil moisture did not even show any detectable increase (Fig. $7 \mathrm{~b}$ ). $R_{\text {eco }}$ on DOY268 suddenly increased to $7.29 \mathrm{~g} \mathrm{C} \mathrm{m}^{-2}$ per day from the background of $0.12 \mathrm{~g} \mathrm{C} \mathrm{m}^{-2}$ per day on the previous day. Then in just 3 days, $R_{\text {eco }}$ plummeted to $0.95 \mathrm{~g} \mathrm{C} \mathrm{m}^{-2}$ per day on DOY271. After the second rain event $\left(12.7 \mathrm{~mm}\right.$ rainfall), the $R_{\text {eco }}$ again greatly increased from $0.05 \mathrm{~g} \mathrm{C} \mathrm{m}^{-2}$ per day on DOY302 to $5.49 \mathrm{~g} \mathrm{C} \mathrm{m}^{-2}$ per day on DOY304. Then, $R_{\text {eco }}$ showed an exponential decrease with time, which was most likely associated with a fast decrease in soil moisture, as soil evaporation is a function of the inverse of the square root of time after a wetting event (Denmead, 1984). With the third rain event, which occurred on DOY315-316 with total precipitation of $51.8 \mathrm{~mm}, R_{\text {eco }}$ increased to $3.28 \mathrm{~g} \mathrm{C} \mathrm{m}^{-2}$ per day and did not show the sharp decrease as the previous two rain events. This could be due to relative large amount of precipitation for that event as shown with consistently high $\theta_{\mathrm{v}}$. It is worth noting that the peak value of $R_{\text {eco }}$ after each rain event showed a gradual decrease. We attributed this observation to the facts that soil temperature became colder and labile carbon pool size at soil surface became smaller.

The sustained rates of respiration after rain were not due to prolonged physical displacement of air by the rain. Both laboratory experiments (Birch, 1958; 


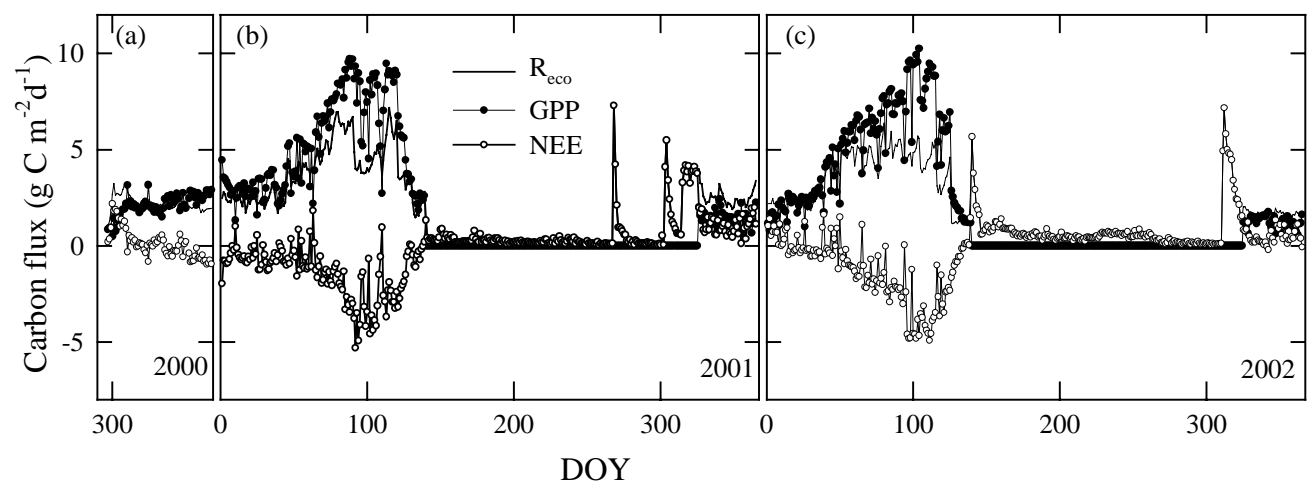

Fig. 8. Seasonal pattern of daily total ecosystem respiration $\left(R_{\mathrm{eco}}\right)$, gross primary production (GPP), and net ecosystem exchange (NEE) over the course of this study from DOY296 (22 October 2000) to the end of the year 2002.

Griffiths and Birch, 1961; Orchard and Cook, 1983) and field measurements (Liu et al., 2002; Rey et al., 2002) show that microbial respiration is able to turn on quickly (within hours) with the addition of water, and respiration rate ceases as soon as the soil layer dries.

\subsection{Seasonal variations and cumulative GPP, $R_{\mathrm{eco}}$, and NEE}

Fig. 8 illustrates the seasonal variations in daily GPP, $R_{\text {eco }}$, and NEE over the course of this study. Due to the earlier rain in the winter of 2000 , the ecosystem started uptaking carbon around DOY297 and showed a slight increase over the wintertime. $R_{\text {eco }}$ was almost unchanged after grass germination, and was very close to GPP, resulting in NEE close to zero. While in the winter of 2001, the grass germinated about 1 month later as compared with the previous year because of late start of the rain. As a result, GPP was consistently lower than $R_{\text {eco }}$, causing positive NEE for the whole winter. In the spring, 2 years showed quite similar pattern of seasonal variations in GPP, $R_{\text {eco }}$, and NEE. Both GPP and $R_{\text {eco }}$ gradually increased in January and February, and NEE was slightly negative. Then as the temperature warmed up and day length increased, GPP and $R_{\text {eco }}$ accelerated in March and April, but with GPP at higher rate, making the ecosystem a strong carbon sink. The daily maximum NEE reached up to $-4.8 \mathrm{~g} \mathrm{C} \mathrm{m}^{-2}$ per day. As the soil dried out in early summer, GPP and $R_{\text {eco }}$ plummeted to near zero around DOY140. In summer, after grass senescence, the grassland continuously lost carbon via soil respira- tion, but at very low rate due to the low soil moisture content.

We observed quite different rates of $R_{\text {eco }}$ in the summer between the 2 years. $R_{\text {eco }}$ in 2001 was in the range of $0.1-0.3 \mathrm{~g} \mathrm{~m}^{-2}$ per day, as compared to that of $0.3-1.2 \mathrm{~g} \mathrm{~m}^{-2}$ per day during the second season (Fig. 8b and c). This contrast in $R_{\text {eco }}$ was probably caused by the difference in soil moisture. As already described in Fig. 1f, just after grass senescence there was a large storm with a total amount of $37 \mathrm{~mm}$ rainfall occurred during DOY139-141 2002. This late spring rain was a source of moisture left in the soil profile. It allowed microbes to decompose carbon substrate at a higher rate and caused the ecosystem to lose more carbon during the dry summer as compared with the previous year. This event can be a source of interannual variability in NEE, as will discuss below.

The maximum values of GPP, $R_{\mathrm{eco}}$, and NEE from the two seasons were very similar, which were around 10.1, 6.5, and $-4.8 \mathrm{~g} \mathrm{~m}^{-2}$ per day, respectively. For comparison, we cite a study conducted over a temperate, $\mathrm{C}_{3}$ grassland near Alberta, Canada. Flanagan et al. (2002) reported similar seasonal maximums of 8.2, 4.0 and -5.0 for GPP, $R_{\text {eco }}$, and NEE during the wet year. Higher values of maximum daily NEE have been reported in other studies of tallgrass, prairies in Kansas and Oklahoma; i.e. $-6.3 \mathrm{~g} \mathrm{C} \mathrm{m}^{-2}$ per day by Kim et al. (1992), $-7.6 \mathrm{~g} \mathrm{C} \mathrm{m}^{-2}$ per day by Dugas et al. (1999), and $-6.0 \mathrm{~g} \mathrm{C} \mathrm{m}^{-2}$ per day by Suyker and Verma (2001). Those higher values may be attributed to larger canopy size and the dominant warm-season $\mathrm{C}_{4}$ species. 


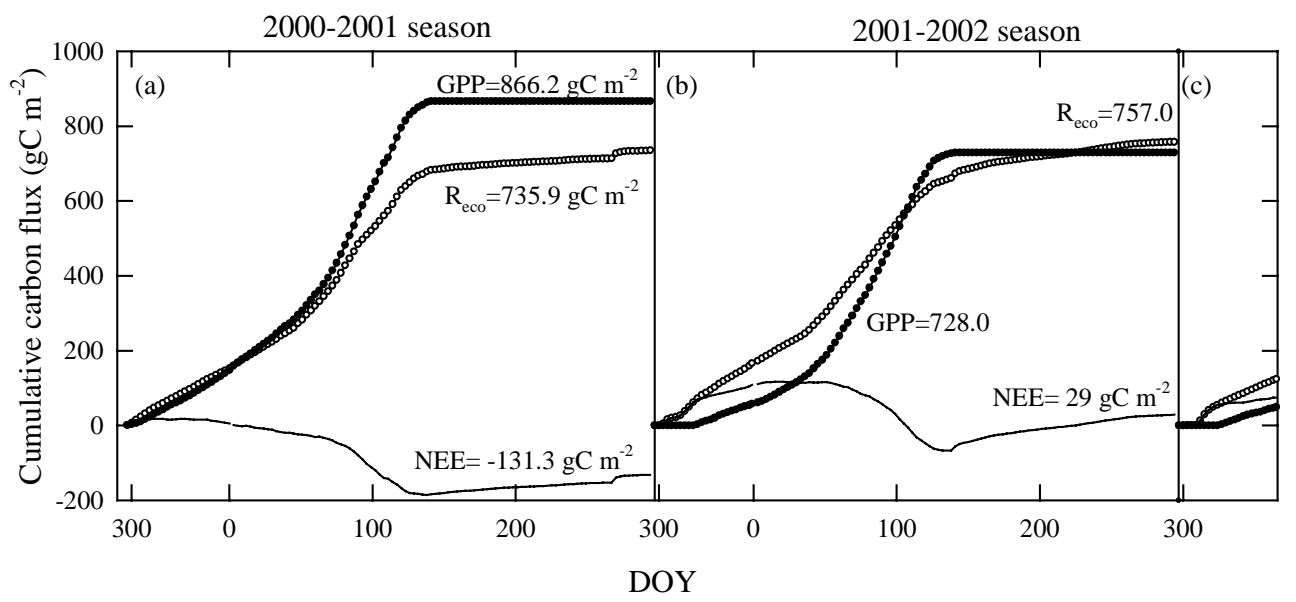

Fig. 9. Cumulative gross primary production (GPP), ecosystem respiration $\left(R_{\text {eco }}\right)$, and net ecosystem exchange (NEE) over the two seasons.

The cumulative GPP, $R_{\text {eco }}$ and NEE over the two seasons (2000-2001 and 2001-2002) were presented in Fig. 9. Since the growing season for the grass is across two calendar years, we did not compute cumulative GPP, $R_{\text {eco }}$ and NEE over the calendar year. Instead, we computed those cumulative parameters based on the growing season of the grass, which is defined as the period from the first major rain event that produced enough precipitation $(>15 \mathrm{~mm})$ for the grass seeds germination to such similar rain event in the next year. As shown in Fig. 9, GPP, $R_{\text {eco }}$ and NEE were 867,735 , and $-132 \mathrm{~g} \mathrm{C} \mathrm{m}^{-2}$ for 2000-2001 season, and 729,758 and $29 \mathrm{~g} \mathrm{C} \mathrm{m}^{-2}$ for 2001-2002 season, respectively. Based on the cumulative NEE data, the grassland was a moderate carbon sink for the first season, while it is a weak source for the second season. As compared to the second season, the ecosystem fixed more carbon, yet respired less during the first season. To better understand this intriguing finding, we divided each grass season into three periods, winter growth, spring growth, and summer non-growth periods (Table 1). Winter growth period was defined as the time from the first major rain event to the 31 December. Spring growth period was defined as the time from 1 January to the senescence of the grass, summer non-growth period from the grass senescence to the beginning of the next season. During the winter period of the first season, due to the earlier start of the grass germination, GPP was $148 \mathrm{~g} \mathrm{C} \mathrm{m}^{-2}$, as compared that of only $58 \mathrm{~g} \mathrm{C} \mathrm{m}^{-2}$ in the same period of the second season. The ecosystem fixed almost $90 \mathrm{~g} \mathrm{C} \mathrm{m}^{-2}$ more carbon than that in the second season, even though precipitation was much less in the first season. Despite the large difference in GPP, the total respiration was comparable for the two seasons (153 and $166 \mathrm{~g} \mathrm{C} \mathrm{m}^{-2}$ ). During the spring growth period, both GPP and $R_{\text {eco }}$ between the two seasons did not show large difference (Table 1). But during the

Table 1

Comparison of precipitation (ppt), ecosystem respiration $\left(R_{\mathrm{eco}}\right)$, gross primary production (GPP), and net ecosystem carbon exchange (NEE) at different growth periods for the two seasons

\begin{tabular}{|c|c|c|c|c|c|c|c|c|c|c|}
\hline \multirow[t]{2}{*}{ Growth period } & \multirow{2}{*}{$\begin{array}{l}2000 \\
\text { winter }\end{array}$} & \multicolumn{3}{|l|}{2001} & \multicolumn{3}{|l|}{2002} & \multirow{2}{*}{$\begin{array}{l}2000-2001 \\
\text { season }\end{array}$} & \multirow{2}{*}{$\begin{array}{l}2001-2002 \\
\text { season }\end{array}$} & \multirow{2}{*}{$\begin{array}{l}\text { Over the whole } \\
\text { course of study }\end{array}$} \\
\hline & & Spring & Summer & Winter & Spring & Summer & Winter & & & \\
\hline ppt (mm) & 120 & 311 & & 255 & 255 & & 239 & 431 & 510 & 1180 \\
\hline$R_{\text {eco }}\left(\mathrm{g} \mathrm{C} \mathrm{m}^{-2}\right)$ & 153 & 528 & 54 & 166 & 498 & 94 & 124 & 735 & 758 & 1617 \\
\hline $\operatorname{GPP}\left(\mathrm{g} \mathrm{C} \mathrm{m}^{-2}\right)$ & 148 & 719 & & 58 & 671 & & 49 & 867 & 729 & 1645 \\
\hline $\operatorname{NEE}\left(\mathrm{g} \mathrm{C} \mathrm{m}^{-2}\right)$ & 5 & -191 & 54 & 108 & -173 & 94 & 75 & -132 & 29 & -28 \\
\hline
\end{tabular}


summer periods, quite different results were observed. Because of late spring rain in the second season after the grass senescence, the soil moisture content was slightly higher than the previous year. As a result of better soil moisture condition, more ecosystem respiration with total carbon loss of $94 \mathrm{~g} \mathrm{C} \mathrm{m}^{-2}$ occurred, as compared to that of $54 \mathrm{~g} \mathrm{C} \mathrm{m}^{-2}$ during the first season. So for the second season late start of growing season combined with better soil moisture in the summer made the ecosystem a weak carbon source. Overall, the system lost $29 \mathrm{~g} \mathrm{C} \mathrm{m}^{-2}$ for the second season, whereas it gained $132 \mathrm{~g} \mathrm{~m}^{-2}$ carbon in the first season. Across the whole study period from October 2000 to the end of 2002, the total carbon uptake was slightly more than the carbon loss via respiration (Table 1).

In the literature, it is well established that annual grassland productivity (normally based on ANPP) is well correlated with annual precipitation across the North American grasslands (Sims and Singh, 1978; Sala et al., 1988). On the temporal level, grassland ANPP has also been shown to have the strongest and positive response to interannual variations in precipitation (Knapp and Smith, 2001). Furthermore, carbon flux measurements with eddy covariance technique also support this well-established view. For examples, from a 3-year eddy covariance measurement over northern temperate grassland in Canada, Flanagan et al. (2002) found that GPP and aboveground biomass production were positively correlated well with annual precipitation. Another flux study conducted over a tallgrass prairie in Okalahoma showed that precipitation is a dominating factor in controlling the NEE (Suyker et al., 2003). From the present study, even with only two-season data, one can still see clearly that the timing of the rain events played much stronger role than total precipitation in determining the GPP and NEE, by influencing the length of the growing season and the ecosystem respiration. This is probably because the growing season of this Mediterranean grassland was confined in the winter and early springtime when potential evapotranspiration was low and usually soil moisture was not limiting factor for carbon uptake. Hence, the widely accepted view of the positive relationship between grass production and precipitation may not hold for Mediterranean types of grassland. The impact of the length of growing season on NEE was also observed from a synthesis based on the carbon flux data across different temperate deciduous forests (Baldocchi et al., 2001).

\subsection{Impact of $U^{*}$ correction on estimate of annual $N E E$}

As we know, the reliability of nighttime $F_{\mathrm{c}}$ measured with eddy covariance method under low turbulent conditions has been questioned (e.g., Aubinet et al., 2002; Massman and Lee, 2002), and there is potential systematic bias on underestimating respiration at night. Among others, poor turbulent mixing, horizontal advection or drainage has been identified as main causes responsible for the underestimation of carbon flux (Massman and Lee, 2002). In Fig. 10a, we present a relation between $U^{*}$ and nighttime $0.5 \mathrm{~h}$ $F_{\mathrm{c}}$. To avoid effects from other variables on $F_{\mathrm{c}}$, data were from the peak growth period (DOY070-120) of 2001. Overall trends shown in the dataset is that $F_{\mathrm{c}}$ was strongly underestimated under low $U^{*}$ condition. Also there appears to exist a $U^{*}$ threshold which was around $0.1 \mathrm{~m} \mathrm{~s}^{-1}$. The lower nighttime $F_{\mathrm{c}}$ under calm conditions has been reported in other studies over forest sites (Goulden et al., 1997; Aubinet et al., 2002) and from grassland sites (Suyker and Verma, 2001; Flanagan et al., 2002). Normally, the data from those conditions have often been corrected to estimate the annual NEE (Falge et al., 2001). One of the most common procedures is to develop a temperature-dependent correction function of $F_{\mathrm{c}}$ obtained during periods of high turbulence when friction velocity $\left(U^{*}\right)$ is above a certain threshold (Aubinet et al., 2002; Flanagan et al., 2002).

It is clear that under low $U^{*}$ conditions half-hour measurements of $F_{\mathrm{c}}$ could be significantly underestimated. How different thresholds in the process of $U^{*}$ correction would affect the estimated annual NEE is less clear, however. Data shown in Fig. 10b illustrate that as $U^{*}$ threshold increased from 0.0 to $0.1 \mathrm{~m} \mathrm{~s}^{-1}$ the estimated NEE became less negative or more positive. Then further increase in $U^{*}$ threshold only slightly affected the estimated NEE. The differences of estimated NEE between uncorrected (i.e. $U^{*}$ threshold $=0 \mathrm{~m} \mathrm{~s}^{-1}$ ) and corrected at the threshold of $0.1 \mathrm{~m} \mathrm{~s}^{-1}$ were only 44 and $34 \mathrm{~g} \mathrm{C} \mathrm{m}^{-2}$ for two seasons, which was near the upper bound of uncertainty of NEE with the eddy covariance technique 


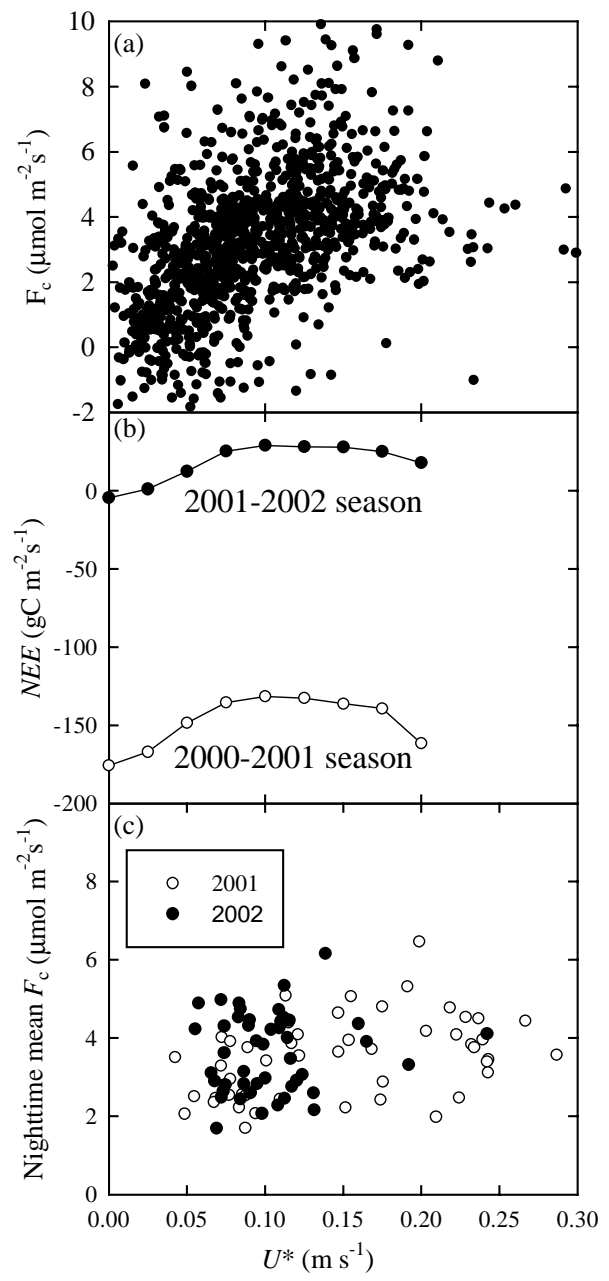

Fig. 10. (a) Influence of friction velocity $\left(U^{*}\right)$ on nighttime $0.5 \mathrm{~h}$ $\mathrm{CO}_{2}$ flux $\left(F_{\mathrm{c}}\right)$. (b) Impact of different $U^{*}$ threshold on estimated annual ecosystem carbon exchange (NEE). (c) Influence of nighttime mean $U^{*}$ on mean $F_{\mathrm{c}}$. To avoid possible confounding effect of soil moisture and grass phenology on ecosystem respiration, only data from the peak growth period (DOY070-120) were included in this analysis of (a) and (c).

(Moncrieff et al., 1996; Goulden et al., 1996a,b). Thus, the impact of using different $U^{*}$ threshold on annual NEE was much less significant than that on the $0.5 \mathrm{~h} F_{\mathrm{c}}$ data. This seems indicating that major portion of respired $\mathrm{CO}_{2}$ from the ecosystem during very stable conditions might not leave the system. On the other hand, the storage term could not entirely account for the decrease in $F_{\mathrm{c}}$ (data not shown). So we

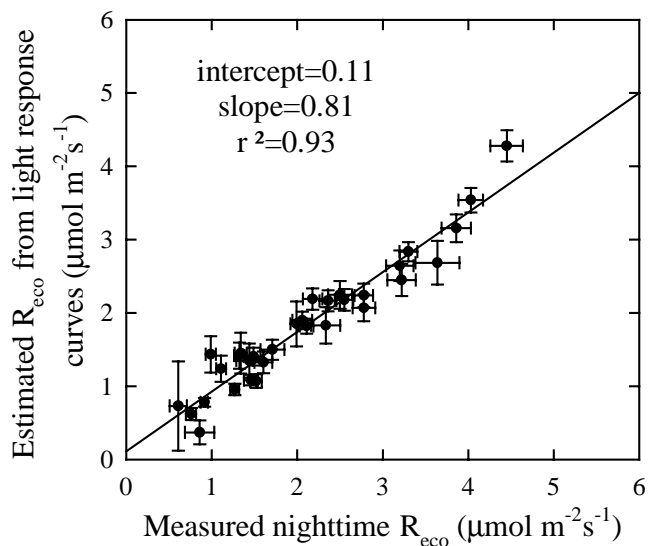

Fig. 11. Ecosystem respiration $\left(R_{\text {eco }}\right)$ determined by using Eq. (4) as compared to the mean of measured nighttime ecosystem respiration.

argue that most of respired $\mathrm{CO}_{2}$ might accumulate at microtopographic troughs under stable condition, and it could flush out and pick up by the eddy covariance system when the air became unstable. Two lines of evidence can be used to support this argument. One is data presented in Fig. 10c, which showed a poor correlation between mean nighttime $F_{\mathrm{c}}$ and $U^{*}$. Another evidence is from the analysis of $R_{\text {eco }}$ using light-response function (Eq. (4)) as shown in Fig. 11. $R_{\text {eco }}$ estimated from light-response curves was correlated very well with the nighttime mean $F_{\mathrm{c}}$. Linear regression (with the mean nighttime $F_{\mathrm{c}}$ as independent variable) yielded a slope of 0.81 and intercept of $0.11 \mu \mathrm{mol} \mathrm{m}{ }^{-2} \mathrm{~s}^{-1}\left(r^{2}=0.93\right)$, demonstrating the reliability of nighttime $F_{\mathrm{c}}$ data. So from this analysis, low $U^{*}$ correction for our site may be not needed to produce accurate annual sums. A similar slope of 0.78 (Suyker and Verma, 2001) or even higher slope of 0.94 (Falge et al., 2002) has been reported from studies over a wide range of functional types, including tropic, Mediterranean, temperate and boreal forests, and $\mathrm{C}_{3}$ and $\mathrm{C}_{4}$ grassland. Some studies have shown that estimated annual NEE was insensitive to $U^{*}$ threshold (Barford et al., 2001), while others shown that the sensitivity was very high (Barr et al., 2002). Thus, $U^{*}$ correction could be site specific, depending on the characteristics of terrain and vegetation, and instrument heights (Aubinet et al., 2002; Massman and Lee, 2002). 


\section{Conclusions}

We presented data from a $\mathrm{CO}_{2}$ flux study over annual grassland in California using the eddy covariance method. Results showed that seasonal trends of both GPP and $R_{\text {eco }}$ followed closely the change in LAI. $R_{\text {eco }}$ followed the exponential function of soil temperature with season-dependent $Q_{10}$ values. We observed large $R_{\text {eco }}$ pulses immediately after rain events, especially those in the non-growing season. During the non-growing seasons from mid-May to September, despite high temperature, severe drought inhibited $R_{\text {eco }}$ to a very low level (less than $1.0 \mathrm{~g} \mathrm{C} \mathrm{m}^{-2}$ per day). Nighttime low $U^{*}$ was showed to have a limited impact on estimated annual NEE and nighttime mean $F_{\mathrm{c}}$, suggesting that drainage may not occur under stable condition. Integrated GPP, $R_{\text {eco }}$, and NEE were 867 , 735 , and $-132 \mathrm{~g} \mathrm{C} \mathrm{m}^{-2}$, respectively, for 2000-2001 season, and 729,758 , and $29 \mathrm{~g} \mathrm{C} \mathrm{m}^{-2}$ for $2001-2002$ season. Higher GPP in the first season was mainly attributed to earlier start of the growing season. Thus, change in length of the growing season due to time of onset of rain was mainly responsible for the variations of annual GPP. So from two-season data, for this Mediterranean grassland, the start of the wet season and the timing of rain event had larger impact than total precipitation on GPP and $R_{\text {eco }}$, and consequently on NEE. More studies are needed to understand how GPP, $R_{\text {eco }}$, and NEE of this Mediterranean grassland respond to a wider spectrum of changes in rainfall patterns due to El Niño and La Niña climate events.

Observations of respiratory pulses after rain events are becoming more common as more investigators report carbon fluxes from Mediterranean ecosystems (Reichstein et al., 2002a,b). The next generation of soil respiration models will need to assess these pulses and the rate they decrease as the upper soil dries, in addition to considering the basal effects of soil temperature and deep soil moisture. To do so we need better information on the physiological mechanisms that describe how soil microbes respond to sudden increase in moisture (Halverson et al., 2000).

\section{Acknowledgements}

This research was supported by Department of Energy, Terrestrial Carbon Program and the California
Agricultural Experiment Station. We especially thank Dr. Joon Kim, who was visiting the Biomet Lab for his sabbatical leave from Yonsei University of South Korea, for the discussion in the writing of this manuscript. Grass species identification and comments by Randy Jackson and Dr. John Battles' group are highly appreciated. We would like to thank Dr. Lianhong Gu, Jianwu Tang and Mr. Ted Hehn for their help in the field work. We also thank Mr. and Mrs. Fran Vaira for access and use of their ranch.

\section{References}

Aubinet, M., Heinesch, B., Longdoz, B., 2002. Estimation of the carbon sequestration by a heterogeneous forest: night flux corrections, heterogeneity of the site and inter-annual variability. Glob. Change Biol. 8, 1053-1071.

Baldocchi, D.D., 2003. Assessing ecosystem carbon balance: problems and prospects of the eddy covariance technique. Glob. Change Biol. 9, 478-492.

Baldocchi, D.D., Falge, E., Gu, L., et al., 2001. Fluxnet: a new tool to study the temporal and spatial variability of ecosystem-scale carbon dioxide, water vapor and energy flux densities. Bull. Am. Meteorol. Soc. 82, 2415-2434.

Baldocchi, D.D., Xu, L., Kiang, N., 2003. How plant functionaltype, weather, seasonal drought and soil physical properties alter water and energy fluxes of an oak-grass savanna and an annual grassland. Agric. For. Meteorol., (in press).

Barbour, M.G., Minnich, R.A., 2000. California upland forests and woodlands. In: Barbour, M.G., Billings, W.D. (Eds.), North American Terrestrial Vegetation. Cambridge University Press, Cambridge, pp. 161-202.

Barford, C.C., Wofsy, S.C., Goulden, M.L., Munger, J.W., Pyle, E.H., Urbanski, S.P., Hutyra, L., Saleska, S.R., Fitzjarrald, D., Moore, K., 2001. Factors controlling long- and short-term sequestration of atmospheric $\mathrm{CO}_{2}$ in a mid-latitude forest. Science 294, 1688-1691.

Barr, A.G., Griffis, T.J., Black, T.A., et al., 2002. Comparing the carbon budgets of boreal and temperate deciduous forest stands. Can. J. For. Res. 32, 813-822.

Bartolome, J.W., 1979. Germination and seeding establishment in California annual grassland. J. Ecol. 67, 73-281.

Birch, H.F., 1958. The effect of soil drying on humus decomposition and nitrogen availability. Plant Soil 10, 9-31.

Bowling, D.R., McDowell, N., Bond, B., Law, B.E., Ehleringer, J., 2002. ${ }^{13} \mathrm{C}$ content of ecosystem respiration is linked to precipitation and vapor pressure deficit. Oecologia 131, 113124.

Bremer, D.J., Ham, J., Owensby, C.E., 1998. Responses of soil respiration to clipping and grazing in a tallgrass prairie. J. Environ. Qual. 27, 1539-1548.

Burba, G.G., Verma, S.B., 2001. Prairie growth, Qp albedo and seasonal distribution of energy fluxes. Agric. For. Meteorol. 107, 227-240. 
Chiariello, N.R., 1989. Phenology of California grasslands. In: Huenneke, L.F., Mooney, H. (Eds.), Grassland Structure and Function: California Annual Grassland. Kluwer Academic Publishers, Dordrecht, Netherlands.

Davidson, E.A., Belk, E., Boone, R.D., 1998. Soil water content and temperature as independent or confounded factors controlling soil respiration in a temperate mixed hardwood forest. Glob. Change Biol. 4, 217-227.

Denmead, O.T., 1984. Plant physiological methods for studying evapotranspiration-problems of telling the forest from the trees. Agric. Water Manage. 8, 167-189.

Dugas, W.A., Heuer, M.L., Mayeux, H.S., 1999. Carbon dioxide fluxes over bermudagrass, native prairie, and sorghum. Agric. For. Meteorol. 93, 121-139.

Ehleringer, J., Cerling, T., Helliker, B., 1997. $\mathrm{C}_{4}$ photosynthesis, atmospheric $\mathrm{CO}_{2}$, and climate. Oecologia 112, 285-299.

Ekbald, A., Högberg, P., 2001. Natural abundance of ${ }^{13} \mathrm{C}$ in $\mathrm{CO}_{2}$ respired from forest soils reveals speed of link between tree photosynthesis and root respiration. Oecologia 127, 305-308.

Falge, E., Baldocchi, D.D., Olson, R.J., et al., 2001. Gap filling strategies for defensible annual sums of net ecosystems exchange. Agric. For. Meteorol. 107, 43-69.

Falge, E., Baldocchi, D.D., Tenhunen, J., et al., 2002. Seasonality of ecosystem respiration and gross primary production as derived from FLUXNET measurements. Agric. For. Meteorol. $113,53-74$.

Flanagan, L.B., Wever, L.A., Carson, P.J., 2002. Seasonal and interannual variation in carbon dioxide exchange and carbon balance in a northern temperate grassland. Glob. Change Biol. 8, 599-615.

Gilmanov, T.G., Verma, S.B., Sims, P.L., Meyers, T.P., Bradford, J.A., Burba, G.G., Suyker, A.E., 2003. Gross primary production and light response parameters of four Southern Plains ecosystems estimated using long-term $\mathrm{CO}_{2}$-flux tower measurements. Glob. Biogeochem. Cycles 17, 1071.

Goulden, M.L., Munger, J.W., Fan, S.-M., Daube, B.C., Wofsy, S.C., 1996a. Measurements of carbon sequestration by long-term eddy covariance: methods and a critical evaluation of accuracy. Glob. Change Biol. 2, 169-182.

Goulden, M.L., Minger, J.W., Fan, S.-M., Daube, B.C., Wofsy, S.C., 1996b. Exchange of carbon dioxide by a deciduous forest: response to interannual climate variability. Science 271 , 15761578.

Goulden, M.L., Daube, B.C., Fan, S.-M., Sutton, D.J., Bazzaz, A., Munger, J.W., Wofsy, S.C., 1997. Physiological responses of a black spruce forest to weather. J. Geophys. Res. 102, 2898728996.

Griffiths, E., Birch, H.F., 1961. Microbiological changes in freshly moistened soil. Nature 189, 424.

Halverson, L.J., Jones, T.M., Firestone, M.K., 2000. Release of intracellular solutes by four soil bacteria exposed to dilution stress. Soil Sci. Soc. Am. J. 64, 1630-1637.

Ham, J.M., Knapp, A.K., 1998. Fluxes of $\mathrm{Co}_{2}$, water vapor, and energy from a prairie ecosystem during the seasonal transition from carbon sink to carbon source. Agric. For. Meteorol. 89, $1-14$.

Högberg, P., Nordgren, A., Buchmann, N., Taylor, A.F., Ekblad, A., Högberg, M.N., Nyberg, G., Ottosson-Lofvenius, M., Read,
D.J., 2001. Large-scale forest girdling shows that current photosynthesis drives soil respiration. Nature 411, 789-792.

Huenneke, L.F., Mooney, H., 1989. Grassland Structure and Function: California Annual Grassland. Kluwer Academic Publishers, Dordrecht, Netherlands, p. 221.

Janssens, I.A., Lankreijer, H., Matteucci, G., et al., 2001. Productivity overshadows temperature in determining soil and ecosystem respiration across European forests. Glob. Change Biol. 7, 269-278.

Kim, J., Verma, S.B., 1990. Carbon dioxide exchange in a temperate grassland ecosystem. Bound. Layer Meteorol. 52, $135-149$.

Kim, J., Verma, S.B., Clement, R.J., 1992. Carbon dioxide budget in temperate grassland ecosystem. J. Geophys. Res. 97, 60576063.

Knapp, A.K., Smith, M.D., 2001. Variation among biomes in temporal dynamics of aboveground primary production. Science 291, 481-484.

Lauenroth, W.K., Sala, O.E., 1992. Long-term forage production of North American shortgrass steppe. Ecol. Appl. 2, 397-403.

Law, B.E., Ryan, M.G., Anthoni, P.M., 1999. Seasonal and annual respiration of a ponderosa pine ecosystem. Glob. Change Biol. $6,169-182$.

Law, B.E., Falge, E., Gu, L., et al., 2002. Environmental controls over carbon dioxide and water vapor exchange of terrestrial vegetation. Agric. For. Meteorol. 113, 97-120.

Law, B.E., Bakwin, P.S., Baldocchi, D.D., Boden, T., Davis, K.J., Hollinger, D., Munger, W.J., Nobre, A., Running, S.W., Wofsy, S.C., Verma, S., 2003. The AmeriFlux network paradigm for measuring and understanding the role of the terrestrial biosphere in global climate change. Bioscience, (submitted for publication)

Liski, J., Ilvesniemi, H., Mäkelä, A., et al., 1999. $\mathrm{CO}_{2}$ emission from soil in response to climatic warming are overestimated - the decomposition of old soil organic matter is tolerant of temperature. Ambio 28, 171-174.

Liu, X.-Z., Wan, S.-Q., Su, B., Hui, D.-F., Luo, Y.-Q., 2002. Response of soil $\mathrm{CO}_{2}$ efflux to water manipulation in a tallgrass prairie. Plant Soil 240, 213-223.

Luo, Y.-Q., Jackson, R.B., Field, C.B., 1996. Elevated $\mathrm{CO}_{2}$ increased belowground respiration in California grasslands. Oecologia 108, 130-137.

Massman, W.J., Lee, X., 2002. Eddy covariance flux corrections and uncertainties in long-term studies of carbon and energy exchanges. Agric. For. Meteorol. 113, 121-144.

Meyers, T., 2001. A comparison of summertime water and $\mathrm{CO}_{2}$ fluxes over rangeland for well watered and drought conditions. Agric. For. Meteorol. 106, 205-214.

Moncrieff, J.B., Malhi, Y., Leuning, R., 1996. The propagation of errors in long-term measurements of lant atmosphere fluxes of carbon and water. Glob. Change Biol. 2, 231-240.

Myneni, R.B., Hoffman, S., Knyazikhin, Y., Privette, J.L., Glassy, J., Tian, Y., Wang, Y., Song, X., Zhang, Y., Smith, G.R., Lotsch, A., Friedl, M., Morisette, J.T., Votava, P., Nemani, R.R., Running, S.W., 2002. Global products of vegetation leaf area and fraction absorbed Qp from year one of MODIS data. Remote Sens. Environ. 83, 214-231. 
Orchard, V.A., Cook, F.J., 1983. Relationship between soil respiration and soil moisture. Soil Biol. Biochem. 15, 447-453.

Paruelo, J.M., Lauenroth, W.K., Burke, I.C., Sala, O.E., 1999. Grassland precipitation-use efficiency varies across a resource gradient. Ecosystems 2, 64-68.

Raich, J.W., Schlesinger, W.H., 1992. The global carbon dioxide flux in soil respiration and its relationship to vegetation and climate. Tellus 44B, 81-99.

Reichstein, W., Tenhunen, J.D., Roupsard, O., Ourcival, J.M., Rambal, S., Dore, S., Valentini, R., 2002a. Ecosystem respiration in two Mediterranean evergreen holm oak forests: drought effects and decomposition dynamics. Funct. Ecol. 16, 27-39.

Reichstein, W., Tenhunen, J.D., Roupsard, O., Ourcival, J.M., Rambal, S., Miglietta, F., Peressotti, A., Pecchiari, M., Tirone, G., Valentini, R., 2002b. Severe drought effects on ecosystem $\mathrm{CO}_{2}$ and $\mathrm{H}_{2} \mathrm{O}$ fluxes in three Mediterranean evergreen ecosystems: revision of current hypothesis? Glob. Change Biol. 8, 999-1017.

Rey, A., Pegoraro, E.P., Tedeschi, V., Parri, I.D., Jarvis, P.G., Valentini, R., 2002. Annual variation in soil respiration and its components in a coppice oak forest in Central Italy. Glob. Change Biol. 8, 851-866.

Ruimy, A., Jarvis, P.G., Baldocchi, D.D., Saugier, B., 1995. $\mathrm{CO}_{2}$ fluxes over plant canopies and solar radiation: a review. Adv. Ecol. Res. 26, 1-68.

Running, S.W., Baldocchi, D.D., Turner, D.P., Gower, S.T., Bakwin, P.S., Hibbard, K.A., 1999. A global terrestrial tower fluxes, flask sampling, ecosystem modeling and EOS data. Remote Sens. Environ. 70, 108-127.

Saigusa, N., Oikawa, T., Liu, S., 1998. Seasonal variations in the exchange of $\mathrm{CO}_{2}$ and $\mathrm{H}_{2} \mathrm{O}$ between a grassland and the atmosphere: an experimental study. Agric. For. Meteorol. 89, 131-139.

Sala, O.E., Parton, W.J., Joyce, L.A., Lauenroth, W.K., 1988. Primary production of the central grassland region of the United States. Ecology 69, 40-45.

Schmid, H.P., 1994. Source areas for scalars and scalar fluxes. Bound. Layer Meteorol. 67, 293-318.

Sims, P.L., Risser, P.G., 2000. Grasslands. In: Barbour, M.G., Billings, W.D. (Eds.), Northern American Terrestrial Vegetation, 2nd ed. Cambridge University Press, Cambridge, pp. 323356.

Sims, P.L., Singh, J.S., 1978. The structure and function of tem western North American grasslands. III. Net primary production, turnover and efficiencies of energy capture and water use. J. Ecol. 66, 573-597.

Suyker, A.E., Verma, S.B., 2001. Year-round observations of the net ecosystem exchange of carbon dioxide in a native tallgrass prairie. Glob. Change Biol. 7, 179-289.

Suyker, A.E., Verma, S.B., Burba, G.G., 2003. Interannual variability in net $\mathrm{CO}_{2}$ exchange of a antive tallgrass prairie. Glob. Change Biol. 9, 255-265.

Tjoelker, M.G., Oleksyn, J., Reich, P.B., 2001. Modeling respiration of vegetation: evidence for a general temperaturedependent $\mathrm{Q}_{10}$. Glob. Change Biol. 7, 223-230.

Turner, D.P., Cohen, W.B., Kennedy, R.E., Fassnacht, K.S., Briggs, J.M., 1999. Relationships between leaf area index and landsat TM spectral vegetation indices across three temperate zone sites. Remote Sens. Environ. 70, 52-68.

Valentini, R., Gamon, J.A., Field, C.B., 1995. Ecosystem gas exchange in a California grassland: seasonal patterns and implications for scaling. Ecology 76, 1940-1952.

Webb, W.S., Szarek, S., Lauenroth, W., Kinerson, R., Smith, M., 1978. Primary productivity and water use in native forest, grassland, and desert ecosystems. Ecology 59, 12391247.

Webb, E.K., Pearman, G.I., Leuning, R., 1980. Correction of flux measurements for density effects due to heat and water vapor transfer. Quart. J. Roy. Meteorol. Soc. 106, 85-100.

Wylie, B.K., Johnson, D.A., Laca, E., Saliendra, N.Z., Gilmanov, T.G., Reed, B.C., Tieszen, L.L., Worstell, B.B., 2003. Calibration of remotely sensed, coarse resolution NDVI to $\mathrm{CO}_{2}$ fluxes in a sagebrush-steppe ecosystem. Remote Sens. Environ. 85, 243-255.

Xu, M., Qi, Y., 2001a. Spatial and seasonal variations of $\mathrm{Q}_{10}$ determined by soil respiration measurements at a Sierra Nevadan forest. Glob. Biogeochem. Cycles 15, 687-696.

$\mathrm{Xu}$, M., Qi, Y., 2001b. Soil-surface $\mathrm{CO}_{2}$ efflux and its spatial and temporal variations in a young ponderosa pine plantation in northern California. Glob. Change Biol. 7, 667677. 